\title{
Wieloznaczność pojęcia „polskości” w narracjach mieszkańców rejonu ostrowieckiego (Białoruś)
}

Nie ma nic co byłoby określone na zawsze: człowiek może zasnąć jako Bałt, a obudzić się jako Słowianin, wyjść z domu jako Polak, powrócić jako Niemiec.

(Babkou 2004: 58)

\section{Abstract}

\section{Ambiguity of the Concept of "Polishness" in the Narratives of the Inhabitants of the Ostrowiec Region (Belarus)}

The article is based on ethnographic research conducted in the Ostrowiec region of Belarus. This region is characterized by the greatest postwar decline of the polish population, across the whole of Belarus (in the 1960s from 65.5\% to 9.8\%). The text presents reflections from the research related the historical awareness of "polish footnote" and their meanings given by the local population, but also covers the ethnic and religious specificities of the region. The last part of the article is narratives of people defined as "the last Poles" - born in the Second Polish Republic polish speaking catholick, who remember the pre-war and war periods.

Keywords: polish minority, Ostrowiec District on Belarus, Belorusian SSR, historical awareness, lithuanian-belarusian borderland, footnote of memory. 


\section{Wstęp}

Rejon ostrowiecki ${ }^{1}$ wraz ze smorgońskim i oszmiańskim stanowią najbardziej wysunięty cypel obwodu grodzieńskiego, który wydawać by się mogło, na mapie wizualnie nie przystaje do reszty obwodu. To obszar przedwojennej Wileńszczyzny, która szeroko rozumiana jest przykładem terenu z wieloma zjawiskami charakterystycznymi dla pogranicza etnicznego. Dziś jest to pogranicze litewsko-białoruskie, ale także wyznaniowe katolicko-prawosławne i bałtycko-słowiańskie. Wielka historia, wielość kultur i kilkakrotna zmiana granic spowodowały, że terytorium określane było mianem: Zachodniej Białorusi, Wschodniej Litwy czy północno-wschodniej Polski (Kowalski 2008: 267). Cezaria Baudouin de Courtenay-Jędrzejewiczowa pisała o specyfice tożsamości mieszkańców Wileńszczyzny: „O poczuciu przynależności do narodu polskiego, litewskiego lub białoruskiego decyduje tylko ludzka wola, ten najistotniejszy we wszystkich dziedzinach czynnik historii" (Baudouin de Courtenay-Jędrzejewiczowa 2005: 392). Anna Engelking nazywa teren Grodzieńszczyzny „pograniczem kulturowym”, rezygnując z takich określeń, jak „etniczny” czy „narodowy”, zwracając przy tym uwagę na zachodzące na tym obszarze oddziaływania poprzez wieki trzech ideologii narodowych: białoruskiej, litewskiej i polskiej (Engelking 1996: 111).

Rejon ostrowiecki wydaje się sztucznie przydzielony do obwodu grodzieńskiego, natomiast pod względem etnicznym, w regionalnej retoryce, można napotkać sformułowania o „siedmiobarwnej tęczy”, ponieważ teren ten od wieków w swojej historii posiada oprócz ludności słowiańskiej i bałtyckiej także wpływy: Żydów, Tatarów, Ormian, Szwedów i Romów (Trojan 2014: 104). Dawniej każda z żyjących na tym terenie nacji posiadała własną przestrzeń życiową i prowadziła odrębną działalność, na przykład Żydzi zajmowali się handlem i finansami, a Tatarzy dawniej kojarzeni byli przede wszystkim z ogrodnictwem, kuśnierstwem i przewozami konnymi (Zaharkevič 2012: 110). Dziś oprócz mieszkańców wsi, katolików definiujących się za pomocą kategorii „tutejszości”, na specyfikę kultury tego obszaru wpływa także katolicka mniejszość litewska. Gierwiaty w rejonie ostrowieckim stanowią jedno z największych skupisk ludności litewskiej na Białorusi (Kowalski 2008: 175). We wsi Rymdziuny ${ }^{2}$ znajduje się szkoła podstawowa i średnia $z$ nauczaniem $w$ języku litewskim, które są pewnego rodzaju centrum kultury i edukacji mniejszości litewskiej na Białorusi³

Przygotowując się do badań, dotarłam do danych, według których rejon ten opisywano jako obszar o największym powojennym spadku liczby ludności identyfikującej się z polskością, w skali całej Białorusi (w latach 60. z 65,5\% do 9,8\%)

${ }^{1}$ biał. Астравецкі раён.

2 biał. Рымдзюны.

${ }^{3}$ Szkoła podstawowa w Rymdziunach została założona w 1994 r., natomiast od 1996 w miejscowości funkcjonuje także litewskojęzyczne liceum. 
(za: Sobecki 2007: 175). Znając dane, postanowiłam w ramach badań przyjrzeć się, kim dla mieszkańców wsi rejonu ostrowieckiego jest „Polak” i jakie znaczenia nadawane są pojęciu „polskości”4. W artykule pokrótce przedstawiam refleksję na ten temat, natomiast w ostatniej części prezentuję opowieści osób definiowanych przez rozmówców jako „ostatni Polacy”, czyli urodzonych w okresie II Rzeczypospolitej i pozostałych po wojnie na terenie Wileńszczyzny polskojęzycznych katolików. Są to osoby pochodzące z polskich bądź mieszanych rodzin, identyfikujące się niekiedy jako Polacy, a niekiedy jako Białorusini polskiego pochodzenia. Natomiast, co ważne dla kontekstu artykułu, są oni przez innych mieszkańców wsi definiowani jako „ostatni prawdziwi Polacy” na tym terenie. Stają się w pełnym słowa znaczeniu świadkami przeszłości - „polskich czasów”, są reprezentantami świata II Rzeczypospolitej, świata, który przestał istnieć wraz z nadejściem wojny i powojennych migracji. Mając na uwadze ówczesną politykę władz wobec mniejszości narodowych i etnicznych na terenie Białorusi, w rozmowach starałam się nie pytać wprost o kategorie narodowościowe, ale raczej o charakter mieszkańców wsi rejonu ostrowieckiego, ich samoidentyfikację, wyobrażenia o historii regionu, jak i o życie codzienne.

\section{Wpływ „wielkiej historii” na specyfikę etniczną regionu}

Wyjątkowość tego terenu i jego mieszkańców opiera się na tym, że doświadczyli oni w ciągu niekiedy jednego pokolenia wielokrotnej zmiany granic państwowych (np. lata 1918-1922, 1939, 1941, 1944), co wpłynęło na ukształtowanie się tożsamości mieszkańców (Demski 2003: 129). Przykładem tej „administracyjnej płynności obszaru" są lata 1946-1955, w których granica Białoruskiej SSR z Polską była kilkakrotnie korygowana. Centralne władze czterokrotnie przesuwały granicę na wschód, umieszczając w Polsce wsie składające się w większości z katolików (Mironowicz 2007: 231). Należy podkreślić, że zmiany kulturowe i świadomościowe ludności nie są wywołane ich emigracją, ale doświadczeniem przesuwa-

${ }^{4}$ Badania prowadzone były w sierpniu 2011 r. na terenie rejonu ostrowieckiego przez grupę etnologów z Katedry Etnologii i Antropologii Kulturowej we Wrocławiu: dr. Mieczysława Trojana, Marcelinę Jakimowicz, Magdalenę Pietrewicz. Na zaproszenie Katedry Etnologii Mińskiego Narodowego Uniwersytetu wspólnie uczestniczyliśmy w badaniach na pograniczu litewsko-białoruskim. Materiał badawczy opiera się na rozmowach z mieszkańcami wsi (19 wywiadów swobodnych z mieszkańcami wsi w wieku 50-80 lat) i wywiadach biograficznych z urodzonymi przed wojną polskojęzycznymi katolikami, określanymi mianem „ostatnich Polaków” (12 wywiadów biograficznych, rozmówcy urodzili się i pamiętali okres II Rzeczypospolitej z perspektywy dziecka). Większość rozmówców była wyznania rzymskokatolickiego, natomiast dwie osoby były prawosławne. Wsie, w których prowadzone były badania: Worniany (biał. Варняны), Gierwiaty (biał. Гервяты), Michaliszki (biał. Міхалішкі), Rymdziuny (biał. Рымдзюны). Większość rozmów prowadzona była w języku rosyjskim, wywiady biograficzne z ludnością urodzoną przed wojną w polskich bądź mieszanych rodzinach odbywały się w większości w języku polskim. 
nia się granic (Demski 2003: 130). Człowiek w sytuacji zmian wywołanych przez działania wojenne zmuszony jest do adaptacji do zmieniających się warunków, do nowych instytucji związanych ze zmianą władzy, języków urzędowych obowiązujących w państwie czy konfrontacji z ludnością napływową.

W kontekście „bycia pomiędzy”, definiowania się poprzez zmieniające się granice, napływające przez wieki grupy etniczne i mieszające się języki powstał na tym terenie pewien rodzaj tożsamości opierającej się na lokalności - „tutejszości”. Definicja tego zjawiska jest dość płynna, jednak polega na definiowaniu się lokalnej ludności poprzez odróżnianie od Polaków i Rosjan bądź jako stan denacjonalizacji albo jako formę lokalnego patriotyzmu (Peršaj 2012: 253). Grzegorz Dąbrowski wiąże „tutejszość” ze zwielokrotnioną tożsamością ukształtowaną wskutek wpływu wielu kultur, mieszania się języków: rosyjskiego, polskiego, litewskiego, białoruskiego, przy tym używania mieszanki językowej zwanej „językiem prostym". Na terenie Wileńszczyzny wiele osób potrafi posługiwać się różnymi językami, w zależności od sytuacji (Dąbrowski 2013: 161-162). Mieszanie się etnicznych typów kultury miało spowodować, że tożsamości były nie tyle płynne, ile raczej stanowiły mozaikę; opierały się nie na wyborze konkretnej tożsamości, ale na przenikaniu się wielu tożsamości (Babkou 2004: 59). Odmienną refleksję snuje Bohdan Cywiński. Zaznacza on, że deklaracja „tutejszości” jest powszechnie traktowana jako świadomość przednarodowa, natomiast należałoby zwrócić uwagę także na kwestie zaufania i jego braku w relacji respondent - pytający, na przykład w ramach spisu powszechnego. Badacz pisze: „Udawanie nieświadomego jest powszechnie znanym i wielekroć sprawdzanym sposobem uniknięcia kłopotów politycznych" (Cywiński 2014: 231). Dla białoruskiego badacza - Andrieja Nasuta - „tutejszość” może być formą, która niczego nie nazywa dokładnie i bezpośrednio, natomiast pozwala wyrazić specyfikę kultury regionu, odczuć i identyfikacji jej mieszkańców (za: Peršaj 2012: 255). Przez wieki władza miała na celu zmuszenie ludności lokalnej do wyboru jednej z narodowych identyfikacji, niekiedy nawet nie tyle zmuszała do jej wyboru, ale określała ją sama.

Badania prowadzone były na terytorium Wileńszczyzny, znajdującym się dziś w granicach Białorusi, w rejonie ostrowieckim, leżącym na terenie obwodu grodzieńskiego. Ten teren pogranicza, jak wspominali wielokrotnie rozmówcy, po II wojnie światowej został „sztucznie” podzielony między dwie republiki: białoruską i litewską. O spontanicznym podziale obszaru świadczy fakt, że w ramach postanowień jałtańskich zastanawiano się nad dwoma wariantami rozwiązania kwestii wileńskiej. Pierwszy z nich zakładał, że cała Wileńszczyzna znajdzie się w granicach Republiki Białoruskiej - taka wizja była bliska władzom sowieckiej Białorusi, które to w propagandzie międzywojennej podkreślały białoruski charakter miasta. O przynależności Wilna do Litwy zadecydowano w Moskwie, bez wiedzy władz białoruskich, prawdopodobnie w 1939 roku (Kowalski 2008: 277). Region wileński został podzielony między dwa obszary państwowe. Wilno w opo- 
wieściach starszych rozmówców stanowi nadal centrum regionu, mimo że dostęp do niego jest utrudniony.

Wojenne działania i powojenne migracje spowodowały, że ludność polska i ocalała z Holokaustu ludność żydowska miały możliwość wyjazdu na tereny północne i zachodnie powojennej Polski. Z obszarów włączonych do Litwy i Białorusi wyemigrowało ok. 50\% ludności polskiej. Przypuszcza się, że do wyjazdu zgłosiła się większa część mieszkańców, jednak władze sowieckie nie pozwalały na migrację, zwłaszcza mieszkańcom wsi, ponieważ groziłoby to ich wyludnieniem (Kowalski 2008: 279). Na podstawie wyników spisów powszechnych największy spadek ludności polskiej nastąpił w latach 60 . Najgorsze rezultaty miał właśnie rejon ostrowiecki (z 65,5\% w spisie w 1959 r. do 9,8\% w 1970 r.). Znaczące różnice dotyczyły także sąsiedniego rejonu oszmiańskiego (spadek z 25\% na 8\%) i iwskiego (z 26,4\% na 11,7\%) (Kowalski 2008: 280). Z 90,2\% katolików na tych terenach jako Polacy określało się w 1959 roku 65,48\%, natomiast w 1999 odsetek wynosił już tylko 10,38\%. Po wojnie w latach 1948-1989 obowiązywał zakaz nauczania języka polskiego, zabraniano drukowania publikacji w języku polskim ${ }^{5}$, natomiast narodzone dzieci miały wpisywaną $\mathrm{w}$ dokumentację od razu narodowość białoruską, zaniżano także w spisach powszechnych liczbę mniejszości polskiej na tym terenie (Głowacka-Grajper 2013: 69). Oczywiście nie tylko Polacy jako mniejszość narodowa podlegali procesom budowania po wojnie „radzieckiego, białoruskiego narodu". Na Białorusi trwały procesy asymilacyjne i praktyki wynaradawiania Polaków, ale także innych grup narodowych i etnicznych, dopiero wraz z upadkiem systemu i odrodzeniem Kościołów i ośrodków społeczno-kulturowych odtworzyła się możliwość rozwoju kultur mniejszościowych (Patek 2001: 320).

Po upadku ZSRR w pierwszym spisie powszechnym w 1989 roku polska mniejszość wynosiła 17\% (Kowalski 2008: 279-280). Jak pisze Artur Patek, ustalenie liczby rzeczywistej ludności polskiej na terenie ZSRR po 1945 roku nie jest łatwe. Wyniki spisów powszechnych dotyczące mniejszości na tych terenach były poważnie zaniżone. Szczególnie gwałtowny i trudny do wytłumaczenia był spadek tej liczby w latach 1959-1970, który nie ma konkretnych przyczyn w postaci na przykład emigracji czy większej umieralności (Patek 2001: 308), a jest powiązany z polityką władz sowieckich wobec mniejszości narodowych i etnicznych zamieszkałych na terenie Białoruskiej SSR. Na zmniejszenie się liczby osób identyfikujących się z polskością niemały wpływ miała także rola Kościoła katolickiego w ugruntowywaniu się tożsamości narodowej Białorusinów. Spadek liczebny ludności polskiej był też wynikiem postępującej asymilacji, na którą wpływała płynność tożsamości i brak identyfikacji na wsiach z jedną ideologią narodową. Oprócz tego spadek liczby mieszkańców regionu identyfikujących się z polskością ułatwiły małżeństwa mieszane, brak możliwości kultywowania

${ }^{5}$ Pewnym wyjątkiem był wydawany w Wilnie w okresie 1953-1990 „Czerwony Sztandar”, jedyny dziennik polskojęzyczny dostępny dla mieszkańców białoruskiej SSR. Dla ludności polskojęzycznej był on jedną z popularniejszych gazet. 
kultury narodowej przy ówczesnym otoczeniu masową kulturą radziecką, która była narzędziem świadomej rusyfikacji ludności przez władzę ZSRR (Patek 2001: 310).

\section{Wieloznaczność pojęcia „polskości”}

Napotkani w czasie badań mieszkańcy wskazywali na swoje polskie, a zarazem białoruskie bądź litewskie korzenie. Częstokroć powtarzały się wypowiedzi: „tut wsie Polaki, no po polsku nie gawarim" bądź „tut Bielarusy, no z korenia Polaki ${ }^{\text {”" }}$ albo „ransze byli tut Polaki, sejczas po polski nikto nie gawari ${ }^{8 ”}$. Polskość w wypowiedziach kojarzyła się z czymś zamierzchłym, z czymś, co przynależało do kategorii „dawnych czasów”, korzeni bądź sfery religijnej, czyli z przynależnością do Kościoła katolickiego. W wypowiedziach były to raczej wzmianki o „śladach polskości”, w rozmowach naturalnie przywoływane, gdy rozmówcy słyszeli mój polski akcent. Polska funkcjonowała również jako kraj sąsiedni, miejsce pracy i edukacji w ramach zagranicznych studiów młodych Białorusinów, a także miejsce życia rodziny, która wyjechała w czasie pojałtańskiej zmiany granic. Jednak te znaczenia nadawane pojęciu „polskości” były rzadsze od znaczeń kategorii „polskości” bliższej przestrzennie, bo tej widocznej w otoczeniu rozmówców, przynależnej do śladów przeszłości.

Co ciekawe, w rozmowach wielokrotnie zaznaczano, iż korzenie większości ludności Wornian i Michaliszek są polskie, mając wtedy na myśli przynależność większości mieszkańców regionu do Kościoła katolickiego, jednocześnie zwracano uwagę na różnorodność kulturową regionu i problematyzację identyfikacji narodowej. We wszystkich wypowiedziach powtarzała się kategoria „mieszane”. Określenie się jako „Polak” dla rozmówców było zależne od kontekstu rozmowy, ale także partnera w dialogu. Błędem jest więc traktowanie tego pojęcia jako równoznacznego $\mathrm{z}$ „byciem świadomym członkiem narodowości”. W zależności od kontekstu może być ono wyrazem utożsamiania się z nacją, z określaniem korzeni swoich przodków bądź identyfikacją z wyznaniem katolickim, na przykład w kontekście bycia nieprawosławnym (Engelking 1999: 181). Pewien mężczyzna w dużym skrócie odpowiedział na pytanie o samoidentyfikację mieszkańców wsi Gierwiaty:

Tut wsie Polaki-katoliki z korenia. Mój dzieduszka Polak i babuszka toże, no ja nie znaju, czy ja polskij Bielorusin ili bieloruskij Polak, no samom Polakiem niet, po polski nie gawarim. Mnoha tut Litwińców, no ja pa litołski nie gawarju, no wsi tut do kostela chodzjat, no ja nie Litwin?.

\footnotetext{
6 Mężczyzna, katolik, ur. ok. 1950, Michaliszki.

Kobieta, katoliczka, ur. 1943, Michaliszki.

${ }^{8}$ Mężczyzna, katolik, ur. ok. 1950, Rymdziuny.

9 Mężczyzna, ur. 1963, katolik, Rymdziuny.
} 
W jednym zdaniu mężczyzna zawarł specyfikę identyfikacji mieszkańców tego pogranicza białorusko-litewskiego. Swoje korzenie określił jako polskie, w przypadku dziadków tożsamość jest oczywista, jednak rozmówca nie określa w tak „pewny” sposób swojej identyfikacji, eliminując kategorie, zaznacza, że nie zna języka litewskiego, to też na pewno nie może być Litwinem. O tej zależności w znaczeniu słowa „Polak” na terenie Grodzieńszczyzny pisze Anna Engelking: „Możemy mówić o dwóch znaczeniach słowa Polak: Jest to, po pierwsze, «katolik», a po drugie: «katolik nie Litwin»" (Engelking 1996: 135).

Język litewski jest jednym z języków, którymi posługuje się mniejszość litewska na tym terenie, choć w regionie większość osób używa w komunikacji codziennej języka białoruskiego w formie gwarowej, który powszechnie określany jest jako język „prosty”. Jest on językiem naturalnym, oczywistym, codziennym, który służy „tylko” do komunikacji bez względu na przynależność religijną czy też do jednej z nacji. Jak zaznaczali rozmówcy, język prosty jest „zwyczajny” - przynależny do sfery życia codziennego i „mieszany”, natomiast języki literackie są określane jako „czyste”, czyli należące do dawnej sfery pańskiej, dziś inteligenckiej czy miastowej (Engelking 1996: 126-127). Rosyjski, jak i białoruski język literacki są bardziej oficjalne, przynależą do przestrzeni edukacji i pracy. Białoruski jest językiem nauczanym w szkole, część rozmówców zwracała uwagę na „opozycyjny charakter” posługiwania się białoruskim. Język rosyjski przynależy natomiast sferze sacrum związanej z cerkwią, a przede wszystkim jest językiem powszechnym w komunikacji ponadlokalnej. Język polski jest związany raczej ze sferą kościoła i modlitwą katolicką, w wariancie regionalnym - „polszczyźnie wileńskiej” używany jest także przez najstarszych mieszkańców wsi, którzy identyfikują się jako Polacy, bądź przez tych, którzy uczęszczali do polskiej przedwojennej szkoły (Engelking 1996: 110).

W czasach radzieckich zlikwidowano trzy czwarte parafii istniejących przed 1945 rokiem, księży zesłano do gułagu bądź wymordowano. W większości w tym okresie wierni modlili się sami w ramach kręgów rodzinnych bądź bardzo bliskich znajomych. Dopiero okres pierestrojki pozwolił na praktykowanie religii w sposób oficjalny, w latach 90. XX wieku nastąpiło żywiołowe odradzanie się Kościołów, w tym katolickiego (Głowacka-Grajper 2013: 69). Religia była ważnym komponentem identyfikacji na tych terenach - jak wspomina Smułkowa na terenie pogranicza szczególną rolę przypisuje się religii, ponieważ najmocniej różnicuje ludzi wyznanie. Na Białorusi katolicyzm jest traktowany jako „polska, litewska wiara”, natomiast prawosławie jako „ruska wiara”. Podział ten jest tak głęboko zakorzeniony, że stał się stereotypem „Polak-katolik”, „Białorusin-prawosławny". Jednak dzisiejsza sytuacja wyznaniowa na terenie wsi rejonu ostrowieckiego przeczy temu stereotypowi, ponieważ wielu rozmówców określających się jako Białorusini należy do Kościoła katolickiego (Smułkowa 2002: 554). Taką sytuację w czasie badań mogliśmy zaobserwować w Wornianach - wsi, w której 
większość mieszkańców chodzi do kościoła katolickiego (msza święta odprawiana jest po litewsku i polsku). Prawosławni są natomiast mniejszością ${ }^{10}$.

Jednym z najważniejszych elementów „polskości” na tych terenach jest Kościół i język polski jako język modlitwy, kazania, spowiedzi, katechezy. Przede wszystkim oddziela on na terenie Białorusi katolików od prawosławnych, jednak na terenie północnej Grodzieńszczyzny język modlitwy definiuje mieszkańca tych terenów, który bądź identyfikuje się z „litewskością”, bądź z „tutejszością”. Niekiedy polski pacierz lub znajomość polskich pieśni są jedynymi formułami, które potrafiła dana osoba powiedzieć po polsku, jednak ten „język modlitwy” powodował, że wobec braku znajomości języka litewskiego rozmówcy definiowali się jako Białorusini o „polskim pochodzeniu”. Iwona Kabzińska określa taką tożsamość mianem „kościelnych Polaków” (Kabzińska 1999). Pacierz jest modlitwą odtwarzaną, co ważne, nauczaną zazwyczaj przez rodziców, dziadków w formie pierwszego zaznajomienia dziecka ze sferą sacrum, wprowadzenia do formy pewnej religijności. Staje się on nośnikiem międzypokoleniowych wartości, symbolem przynależności do Kościoła, którego przeciwieństwem jest Cerkiew (Engelking 2001: 88). Częstokroć w przypadku młodszych pokoleń jest to tylko język modlitwy i przestrzeni sakralnej, mimo wprowadzenia języka białoruskiego do kościoła nadal utrzymywana jest tradycja nauki pacierza po polsku, ponieważ jest on językiem odmiennym od tego codziennego, służącego do komunikacji lokalnej. Przykładem z badań terenowych jest sytuacja z mszy świętej w Wornianach. Jedna $\mathrm{z}$ kobiet po nabożeństwie poprosiła, bym napisała po polsku wypominki za jej męża. Po wrzuceniu ich do skrzynki kobieta wzruszyła się i powiedziała: „Mąż był Polak, ja trochę Polka, ale nie piszę po polsku, a to Bóg, ale i mąż bardziej zadowolony teraz będzie"11. Jak pisze Engelking: „Język sacrum nie może być tożsamy z językiem codziennym. Musi być inny, niecodzienny, wyjątkowy, lepszy, piękniejszy... Dlatego, nawet jeśli się go nie rozumie, wszystko jest w porządku" (Engelking 2001: 90).

\section{"Ostatni prawdziwi Polacy" - opowieści rozmówców urodzonych przed wojną}

Podczas badań terenowych rozmówcy, słysząc polski akcent, kierowali mnie do tak zwanych ostatnich Polaków. Wojna, deportacje i okres stalinowski doprowadziły do wyczyszczenia etnicznego tych terenów, nastąpiła homogenizacja społeczności, rozdzielenie rodzin i sąsiedzkich wspólnot (Zowczak 1998: 26).

${ }^{10}$ We wsi jest parafia katolicka, do której na msze święte uczęszcza większość mieszkańców, natomiast w prywatnym domu (jak mówili rozmówcy), w budynku po byłej aptece, została utworzona cerkiew prawosławna.

${ }^{11}$ Kobieta, katoliczka, ur. 1930, Worniany. 
Opowieściom tych osób - „ostatnich Polaków” na wsiach rejonu ostrowickiego przyjrzę się dokładniej. Interesujące, że są oni przedstawiani przez mieszkańców wsi jako postacie wyjątkowe - określani jako „prawdziwi”, „ostatni” Polacy. Wspólną cechą tych rozmówców jest: urodzenie się w czasach II Rzeczypospolitej, w rodzinach polskich bądź mieszanych, uczęszczanie do polskiej szkoły, przeżycie wojny, jak i przynależenie do Kościoła katolickiego i posługiwanie się językiem polskim.

Zaznaczano, że są oni przykładem świata, który odchodzi, byli ostatnimi świadkami II Rzeczypospolitej, zachęcano nas do odwiedzenia ich i rozmowy słowami: „A jeszcze adna babuszka - Polka żywiot. Sama ostalas”"12. Niewątpliwie te pojedyncze historie ludzkie są interesujące z perspektywy dzisiejszego bycia w mniejszości, reprezentowania pamięci o przeszłych czasach z perspektywy określonej polskiej narodowości. W mniemaniu mieszkańców wsi „ostatni Polacy" byli w pełnym znaczeniu tego słowa świadkami historii. Staje się nim ten, kto naocznie doświadczył pewnego wydarzenia - „bycie tam” powoduje, że człowiek może pośredniczyć i przekazywać historię „tu i teraz”. Świadek ma uprawnienia do opowiadania historii poprzez swoje doświadczenia (Wejland 2013: 121). Ponieważ wywiad ze świadkami historii stanowi subiektywny akt pamięci, oczywistością jest, że może zawierać błędy faktograficzne, osobiste interpretacje wydarzeń historycznych, pomyłki, przeoczenia, jednak, jak pisze Alessandro Portelli, owe pomyłki mogą zaprowadzić „ponad fakty” - ukazać znaczenia, jakie są nadawane wydarzeniom przez świadków (za: Filipkowski 2010: 23). Świadectwo jest tym samym próbą przekazywania doświadczenia, i to przekaz jest najważniejszy w samym „zaświadczaniu”. Rozmówcy, określani przez mieszkańców rejonu ostrowieckiego jako „ostatni Polacy”, byli świadkami świata, który odszedł, żyli w II Rzeczypospolitej, jak i posługiwali się językiem polskim na co dzień, członkowie ich rodzin i znajomi wyjechali po wojnie na teren zachodniej i północnej Polski.

Dla rozmówców okres przedwojenny był czasem dzieciństwa i młodości, momentem nierozerwanych rodzin i sąsiedzkich wspólnot, natomiast wojna w opowieściach zniszczyła społeczność lokalną i zmieniła ją diametralnie. „Ostatni Polacy” z nostalgią wspominali i porównywali czas II Rzeczypospolitej do powojnia i współczesności, zaznaczali kres świata, który był im znany:

Ja tak nieraz myślę - Boże, żeby jeszcze nie umrzeć, żeby wróciły te dobre, polskie czasy, ja już nieprawidłowo rozmawiam po polsku. (...) Żeby można było z kimś [rozmawiać], a to kilka lat nie rozmawiałam, kilkanaście [lat]... ale ja nie mam z kim rozmawiać, nie ma tu nikogo ${ }^{13}$.

Rozmówczyni wspominała z tęsknotą czasy, w których w domu obok mieszkała jej znajoma - Polka, której rodzina także nie wyjechała podczas powojennych

12 Kobieta, prawosławna, ur. 1955, Michaliszki.

${ }^{13}$ Kobieta, katoliczka, ur. 1933, Worniany. 
przesiedleń. W czasach II Rzeczypospolitej rozmówcy byli dziećmi, więc na ten okres przypadły pierwsze dziecięce bądź młodzieńcze wspomnienia. O wielokulturowym charakterze Wileńszczyzny południowej mówią we wspomnieniach dotyczących lat szkolnych, dla przedwojennych Polaków to „czasy polskie”, które powiązane są z okresem spokoju i stabilizacji:

Za polskich czasów żyło się bardzo dobrze, mieliśmy swoją gospodarkę, ja skończyłem siedem klas. O taka sprawa, że teraz zdaje mi się, że nie ma tej szkoły, kiedyś szkoła w Wornianach była, też zlikwidowali szkołę. Było Białorusów i Polaków, większa część Polaków była, a mniejsza część Białorusów. Jakiegoś podziału tam nie było ${ }^{14}$.

„Czasy polskie” wielokrotnie były porównywane w narracjach do późniejszego okresu kolektywizacji, zaznaczano złą sytuację i wyzysk lokalnej ludności pracującej w kołchozach. W każdej opowieści natomiast rozmówcy porównywali oba okresy, osią zmian była wojna i decyzje o wyjeździe bądź pozostaniu. Okres II Rzeczypospolitej w narracjach rozmówców był opisywany z perspektywy mitu kresowej arkadii, traktowany jako czas utęskniony, był nie tylko czasem odzyskania niepodległości przez Polskę, ale także był mityzowany jako czas dzieciństwa i młodości, który zawsze podlega nostalgii. Powojenny czas w kontekście opowiadanych historii życia był definiowany jako najcięższy, kolektywizacja doprowadziła do zubożenia ludności, częstokroć w opowieściach rozmówców powojenne czasy kojarzą się z głodem, biedą i wyzyskiem:

W kołchozach te ludzie pracowali za darmo, a żyli tylko ze swoich ogrodów, kto ogród miał, to żył jakoś. To co koło domu [posadzili], to z tego przeżywali. A tak pracuje, pracuje cały rok, a kilka kilogramów [zboża] dostanie, zarzuci [na plecy] i niesie, takie było znęcanie. A mi też zabrali [ziemię]. U nas było 12 hektarów ziemi. Za polskich czasów żyło się bardzo dobrze, żyli $\mathrm{w}$ dostatku ${ }^{15}$.

Jednym z pojawiających się motywów była kwestia powojennych wyjazdów, podziału rodzin i wspólnot lokalnych. Każdy z rozmówców przedstawiał sytuację i kontekst powodów pozostania na terenie białoruskiej SRR:

W większej części młodzież wyjechała do Polski, a moi rodzice zatrzymali się, nie wyjechali, to i ja zostałem. A dlatego [rodzice] zostali, że taki jeden ruski facet powiedział: „My tam jesteśmy, czerwona Polska [jest]. Komunistyczna prawda”. Matka zamachała rękami i powiedziała: „O nie, to mnie takiej Polski nie trzeba" [śmiech - dop. M.J.]. Od nas dużo wyjechało, mało kto tam został ze starożyłych. Po większej części do Szczecina [pojechali]... Tam ruska władza wyznaczała miejsce i do Szczecina w większej części [pojechali] nasi, byłem parę razy w Polsce. Zjeździłem też w dół i w poprzek [Polskę $]^{16}$.

W powyższej wypowiedzi wiadomość o socjalistycznym ustroju w powojennej Polsce powoduje niechęć rodziców rozmówcy do wyjazdu. Opowieść ta przed-

\footnotetext{
${ }^{14}$ Mężczyzna, katolik, ur. 1926, Ostrowiec.

${ }_{15}$ Kobieta, prawosławna, ur. 1936, Worniany.

${ }^{16}$ Mężczyzna, katolik, ur. 1926, Ostrowiec.
} 
stawiona była przez mężczyznę ze śmiechem, choć nie ulega wątpliwości, że po zawierusze wojennej kwestie spokoju, stabilności i pewnego miejsca na ziemi małej ojczyzny, miały ogromne znaczenie. Decyzja o porzuceniu ojcowizny, rezygnacji z rodzinnej ziemi i podjęciu ryzyka życia w nowym miejscu, na ziemiach zachodnich powojennej Polski, wielokrotnie przewijała się w opowieściach rozmówców:

Zrazu po wojnie jakoś było takie rozporządzenie, że kto liczy się Polakiem, ma polską narodowość, to może wyjeżdżać. A moi jako Polacy... I ojciec Polakiem liczył się, w dokumentach było [że on Polak] już był staruszkiem, a dokumenty miał, że on Polak. I matka też Polka. Od początku mieszkali w Izabelinie, to zostali ${ }^{17}$.

Po wojnie na Białorusi powrócono do carskiej polityki względem mniejszości narodowych i etnicznych, do 1949 roku zlikwidowano polskie szkoły i instytucje. Po II wojnie światowej i emigracjach szacuje się, że na Białorusi pozostało ok. 500 tysięcy Polaków, których to poddano przymusowej białorutenizacji, choć na modłę radziecką (Darski 1993: 73). W latach 60. XX wieku nastąpiła wymiana dokumentów tożsamości, którą wykorzystano, by zmienić narodowość. Jedna z rozmówczyń wspomina: „Ja Białoruska. Mamusia «Polka» napisane [w dokumentach]. Tatuś ma Polak [w dokumentach]. A ja Białoruska (...) Od razu to nie [zmieniali dokumentów], pisali Polakami. Potem zmieniali. Czasem to gwałtem zmuszali, żeby ludzie nie pisali, że Polaki. Wot"18. Wymiana dokumentów w latach 50.-60. XX wieku i przymusowe wpisywanie białoruskiej tożsamości zaważyły na zaniżeniu statystyk mniejszości polskiej terytorium obwodu ostrowieckiego, to wydarzenie nadal dla rozmówców jest ważnym wspomnieniem:

Tylko po wojnie było takie, jak się nazywa komunistyczeskie prawo, pamiętam dzieci jak rodziły się, jeden syn, drugi syn, ja registrowałem do zaksu' ${ }^{19}$. [Trzeba było tam zarejstrować], bo inaczej księża nie chrzcili, gdy dokumentu do zaksu nie miało dziecko. A wtedy już... a ja mówię: „Ja Polak jestem”, a oni przekreślają i piszą Białorus. Gwałtem to. A co zrobię? Nic nie wskórasz. Takie rozporządzenia były dane księżom. Żeby trzymać wszystko w swoich rękach ${ }^{20}$.

Dodatkowym elementem wpływającym na spadek ludności identyfikującej się z polskością miały działania władz w latach 60.-70. XX wieku, skierowane wobec ludności zamieszkującej te tereny. W tych latach szkolnictwo ostatecznie zrusyfikowano. Dla awansu społecznego, ekonomicznego, kulturalnego należało oglądać radzieckie filmy, rozmawiać po rosyjsku - przyjąć sowiecki uniwersalizm. W latach 70. nastąpiła stabilizacja - ludzie pamiętali jeszcze strach i nędzę czasów stalinowskich, „wielka sowiecka ojczyzna” była symbolem dobrobytu, mo-

17 Mężczyzna, katolik, ur. 1930, Worniany.

${ }_{18}$ Kobieta, katoliczka, ur. 1943, Michaliszki.

19 ЗАГС - Органызаписиа кто вгражданского состояния - w Białorusi i Rosji odpowiednik akt stanu cywilnego w Polsce.

20 Mężczyzna, katolik, ur. 1926, Ostrowiec. 
carstwem w skali światowej (Waszkiewicz 2010: 80). Dla zrozumienia tożsamości mieszkańców wschodniej Wileńszczyzny i procesów drastycznego spadku ludności polskiej, którego idealnym przykładem jest teren północnej Grodzieńszczyzny, należy przyjrzeć się procesom rusyfikowania ludności lokalnej nie tylko polskiej, ale i białoruskiej czy litewskiej.

[Na tym terenie] Polacy katolicy byli i Litwini katolicy. Po wojnie to [ludzie] w większej części po białorusku rozmawiają, ten teren jako Białoruś się liczy i telewizory też po rosyjsku. Mnie to wszystko jedno, ja i tak, i tak [rozmawiać umiem]. Ja i czytam po polsku, niektórzy to nie [czytają]. Książeczki są do nabożeństwa, wydania takie z Polski przywożone przez księży. Dużo takich jest z prewodem, po białorusku i po polsku, ja tak tylko śmieję się... Teraz nie mówi się po polsku, w szkołach są specjalne klasy i do tej klasy zapisują rodzice, żeby dzieci się uczyły polskiego języka, jak obcego - angielskiego ${ }^{21}$.

Słaba tożsamość narodowa Białorusinów spowodowana masowymi represjami w okresie od lat 20. do 50. XX wieku, obsadzanie stanowisk kierowniczych ludnością ze Wschodu, totalna rusyfikacja i sowietyzacja, doprowadziły do stworzenia na tym pogranicznym terenie człowieka sowieckiego. Definiowanie się mieszkańców wsi jako „tutejsi” w latach powojennych zostało wykorzystane przez władze do wprowadzenia kategorii „człowieka radzieckiego” - Białorusina mówiącego po rosyjsku, spoglądającego z nostalgią na czasy stabilizacji w ZSRR (Waszkiewicz 2010: 86). Dość mocną tezę stawia Jerzy Waszkiewicz, który zaznacza, że na Białorusi oprócz grupy mniejszościowej - świadomych Białorusinów, istnieje większość, która charakteryzuje się sowiecko-wiejskim sposobem życia: „Są rosyjskojęzycznymi tutejszymi, utożsamiającymi się z miejscem swego zamieszkania, a nie całym narodem i państwem, którego wartości posiadania nie odczuwają" (Waszkiewicz 2010: 87). Choć te słowa dość radykalnie przedstawiają problem tożsamości współczesnych obywateli Białorusi, to zwracają uwagę na problem wpływu rusyfikacji i sowietyzacji mieszkańców Białorusi w latach powojennych bez względu na ich wyznanie, identyfikację czy język, jakim się posługują. Anna Engelking utożsamia „tutejszego" z dzisiejszym białoruskim kołchoźnikiem, związanym z ziemią, wpisanym w mikrokosmos składający się ze wsi, kołchozu i parafii (Engelking 2013: 191). Upadek Związku Radzieckiego, zmiany społeczne i gospodarcze, jakie nastały, dały możliwość dojścia do głosu wszystkim obywatelom Białorusi. Jednak nieobecność wymordowanej w latach powojennych inteligencji białoruskiej, prestiż języka rosyjskiego oraz pogarszająca się sytuacja gospodarcza kraju spowodowały, że podstawowym problemem obywateli Białorusi po upadku ZSRR są kwestie ekonomiczne, a nie kategorie tożsamościowe i kwestie narodowe (Waszczyńska 2013: 215).

${ }^{21}$ Kobieta, katoliczka, ur. 1934, Wormiany. 


\section{Podsumowanie}

We wsiach regionu ostrowieckiego w wypowiedziach rozmówców pojęcie „polskości” jest wieloznaczne i zależne od kontekstu rozmowy, jak i tożsamości partnera dialogu: określa ono zarówno polskie korzenie mieszkańców, przynależność do Kościoła katolickiego, jak i odrębność od litewskojęzycznych katolików zamieszkałych na tym terenie. Kategoria „polskości” jest płynna i zazwyczaj w opowieściach rozmówców nie jest tożsama z przynależnością do polskiej nacji. Zaznaczenie w rozmowach polskiego czy litewskiego pochodzenia przodka staje się także ukazaniem wielokulturowości tych terenów, na tak małej grupie elementarnej, jaką jest rodzina. Na tym terytorium istnieje kilka języków, które przynależą do sfer życia. Ponieważ teren „białoruskiej Wileńszczyzny” jest zamieszkany przez największą enklawę Litwinów na Białorusi, którzy w większości należą do Kościoła katolickiego, identyfikacja odbywa się względem bycia bądź nie Litwinem, czyli posługiwania się językiem litewskim.

Powojenna polityka narodowościowa władz ZSRR polegała na: sowietyzacji, rusyfikacji i rozpowszechnianiu ateizmu. Narzędziem polityki władz stały się szkoła i środki masowego przekazu. Polacy na różnych obszarach ZSRR byli traktowani odmiennie, władze prowadziły politykę regionalizacji, ustaloną przez Stalina, która polegała na zróżnicowanym traktowaniu Polaków: od przyznania ograniczonych praw (na przykład na Litwie, Ukrainie zachodniej), do aktywnej rusyfikacji na terenie Białorusi. Ten proces dotyczył wszystkich mieszkańców białoruskiej SSR, również Białorusinów czy Litwinów (Patek 2001: 314). Opowieści o polskich czasach, jak i lokalnej identyfikacji są związane z działaniem wielkiej historii na tych terenach i wpływem w szczególności powojennych migracji, jak i procesu tworzenia „radzieckiego Białorusina” i przymusowej sowietyzacji, która dotknęła nie tylko Polaków na Białorusi, ale wszystkich jej mieszkańców. Wieloznaczność pojęcia „polskości” wśród mieszkańców wybranych wsi regionu ostrowieckiego związana jest ze specyfiką etniczną tego terenu, ale także z jego pogranicznym charakterem. Pojęcie polskości w rozmowach nabierało znaczenia wobec innych pojęć, w zależności od sytuacji i kontekstu rozmowy mogło mieć odmienne znaczenia. Polakiem nazwany mógł być każdy katolik, jednak nie Litwin, polskość mogła być także kategorią odziedziczoną jako wyznanie po dziadkach czy rodzicach. Mieszkańcy wsi regionu ostrowieckiego określali mianem „ostatnich prawdziwych Polaków” urodzonych przed wojną polskojęzycznych katolików, którzy mieli możliwość wyjazdu po jałtańskiej zmianie granic na tereny zachodniej i północnej Polski. Ich historie życia były przedstawiane jako atrakcyjne, bo wyjątkowe, ponieważ związane ze światem przeszłości II Rzeczypospolitej.

Większym znaczeniem w identyfikacji rozmówców niż nacja bądź język dla mieszkańców wsi regionu ostrowieckiego była opozycja „wiejski-miastowy”, która realizowała się zarówno w narracjach i znaczeniach nadawanych językowi, jak i wykonywanej przez rozmówców pracy (Engelking 2013: 195). 


\section{Bibliografia}

Babkou I.

2004 Białoruś kraina otoczona wysokimi górami, Olsztyn 2004.

Baudouin de Courtenay-Jędrzejewiczowa C.

2005 Grupy etniczne na ziemiach Wielkiego Księstwa Litewskiego, w: C. Baudouin de Courtenay-Jędrzejewiczowa. Łańcuch tradycji. Teksty wybrane, wyb. L. Mróz, A. Zadrożyńska, Warszawa, s. 359-400.

Cywiński B.

2014 Dzieje narodów Europy Wschodniej. Szańce kultury, Warszawa.

Darski J.

1993 Białoruś. Historia, wspótczesność, konflikty narodowe, Warszawa.

Dąbrowski G.

2013 Prosta etnografia Wileńszczyzny, Wrocław.

Demski D.

2000 „Najważniejsze, żeby pamiętać”... Cmentarz jako źródło do badań tożsamości zbiorowej mieszkańców wsi na Białorusi i ich wyobrażeń na temat śmierci, „Etnografia Polska”, nr 44 (1-2), s. 79-98.

Demski D.

2003 Pogranicze jako patchwork. Refleksje z Białorusi, „Etnografia Polska”, nr 47 (1-2), s. $129-148$.

Engelking A.

1996 Nacje, to znaczy grupy religijne, „Kultura i Społeczeństwo”, nr 40 (1), s. 109-139.

Engelking A.

1999 The Natsyas of the Grodno region of Belarus: A Field Study, „Nations and Nationalism", nr 5 (2), s. 175-206.

Engelking A.

2001 Pozasakralne funkcje pacierza. Z obserwacji etnografa na pograniczu katolicko-prawosławnym na Grodzieńszczyźnie, „Etnolingwistyka”, nr 13, s. 85-100.

Engelking A.

2013 Proste robocze ludzie chrześcijanie, czyli wizerunek własny białoruskich kołchoźników. Konkluzje antropologa po dwóch dekadach badań terenowych, w: Etnograficzne wędrówki po obszarach antropologii, red. Ł. Smyrski, K. Waszczyńska, Warszawa, s. 189-208.

Filipkowski P.

2010 Historia mówiona i wojna. Doświadczenie obozu koncentracyjnego w perspektywie narracji biograficznej, Wrocław.

Głowacka-Grajper M.

2013 Zbiorowości polskie w zachodnich republikach byłego ZSRR, „Studia BAS”, nr 34 (2), s. 51-84.

Kabzińska I.

1999 Wśród „kościelnych Polaków”: Wyznaczniki tożsamości etnicznej (narodowej)

Polaków na Białorusi, Warszawa.

Sobecki M.

2007 Kultura symboliczna a tożsamość. Studium tożsamości kulturowej Polaków na Grodzieńszczyźnie z perspektywy edukacji międzykulturowej, Białystok. 


\section{Kowalski M.}

2008 Wileńszczyzna jako problem geopolityczny w XX wieku, „Prace Geograficzne”, nr 218, s. 267-296.

Mironowicz E.

2007 Białoruś, Warszawa.

Patek A.

2001 Polska diaspora w Rosji Radzieckiej i ZSRR, w: Polska diaspora, red. A. Walaszek, Kraków, s. 293-316.

Peršaj A.

2012 Tutèjšasc' kak taktika kul'turnogo soprotiveniâ: lokal'nosti, social'noj mobil'nostii belarusskoj nacional'noj identičnosti, „Forum novejšej vostočnoevropejskoj istoriii kul'tury", nr 2, s. 251-268.

Smułkowa E.

2002 Białoruś i pogranicza. Studia o języku i społeczeństwie, Warszawa.

Sobecki M.

2007 Kultura symboliczna a tożsamość. Studium tożsamości kulturowej Polaków na Grodzieńszczyźnie z perspektywy edukacji międzykulturowej, Białystok.

Trojan M.

2014 Środowisko lokalne, życie codzienne, przemiany kulturowe (rejon ostrowiecki obwodu grodzieńskiego), „Wrocławskie Studia Wschodnie”, nr 18, s. 103-115.

Waszczyńska K.

2013 „Do” czy „na” Białorusi - refleksje o współczesnym narodzie i państwie białoruskim, w: Etnograficzne wędrówki po obszarach antropologii, red. Ł. Smyrski, K. Waszczyńska, Warszawa, s. 209-221.

Waszkiewicz J.

2010 Europa czy „Azjopa”?, w: Białoruś. Przeszłość i teraźniejszość. Kultura. Literatura. Język, red. R. Radzik, M. Sajewicz, Lublin, s. 79-93.

Wejland A.P.

2013 Antropolog i pojęcie świadectwa. O niektórych pułapkach $w$ badaniu terenowym, w: Tematy trudne. Sytuacje badawcze, red. I.B. Kuźma, Łódź, s. 111-142.

Zaharkevič S.A.

2012 Ėtničeskie men’šinstva Belarusi XIV-XVIII vv. v sovremennoj pol'skoi istoriografii, w: Krynicaznaŭstva ì specyâl'nyâ gìstaryčnyâ dyscypliny navuk, vyp. 7, red. S.M. Hodzín, Mínsk, s. 109-117.

Zowczak M.

1998 Brasławszczyzna, białoruska prowincja. Szkice z kultury symbolicznej, „Konteksty. Polska Sztuka Ludowa”, nr 52, s. 26-27. 